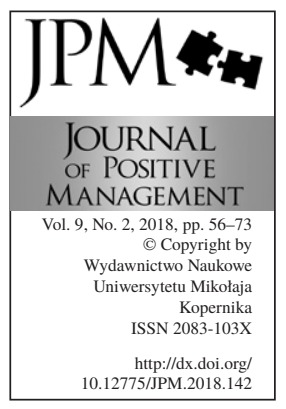

\title{
USING OUR COMPETENCE WHEN WE INCORPORATE SOCIAL RESPONSIBILITY
}

\author{
Kassaye Deyassa \\ University of Bergen, Bergen, Norway \\ e-mail: kde001@uib.no
}

\begin{abstract}
Purpose: The main purpose this article is to assess how individuals react to firms that up hold activities in corporate social responsibilities. In the aftermath of the economic crisis, a new form of corporate social responsibility (CSR) is emerging. To restore the trust of capitalism as a system and for companies, social responsibility has gained lots of attention. There are several diverse ways firms can demonstrate responsibility for society, for example through sponsorship responsibility for the environment or responsibility for firms' employees, partners and suppliers.

Methodology: The survey utilised the use of both primary and secondary data. Published articles, websites and other credible sources were utilised in assessing the findings from the previous researchers. Also, raw data was collected from a selected sample of individuals in both employees', investors' and customers' perspectives.
\end{abstract}

Finding: The results the study shows that there are high levels of compliance between social activity and competence have a positive impact on customers' perception of the company's goodwill and integrity but do not affect how customers assess company's core competence.

Keywords: Corporate Social Responsibility, Creation of Shared Values, Trust, Ability, Goodwill, Integrity, Experiment

Paper type: Research paper

\section{Introduction}

In the aftermath of the economic crisis, a new form of corporate social responsibility (CSR) is emerging. To restore the trust of capitalism as a system and for companies, social responsibility has gained lots of attention. Several companies have CSR on the agenda and are committed to communicating to customers that they take responsibility for the society. There are several definitions of what social responsibility is. Carroll (1991) probably has the most well-known definition in which he shares that social responsibility is economic, legal, ethical and philanthropic responsibility, which builds on the most fundamental economic responsibility of most fundamental philanthropic responsibility. Philanthropy is 
based on companies taking responsibility beyond what is expected and required

by a company. In other words, CSR activities do not need to be related to the company's core competencies.

Following the economic crisis in 2008, Porter and Kramer (2011) introduced an expanded perspective on corporate social responsibility. The perspective implies that social responsibility should create value for both, companies and society, at the same time. The perspective is referred to as the creation of shared values (CSV) and is based on increasing the efficiency of CSR activities by anchoring them in company's core competence (Porter and Kramer, 2011). Several researchers have found that compliance between the company and its activities has a positive effect on customers' evaluation of company and its activities (Becker-Olsen et al., 2006). In this case, it indicates that compliance between a CSR activity and the company's core competence may have a positive impact on customer's evaluation of company's confidence compared with traditional CSR activities.

CSR has several positive aspects. According to Romani, Grappi and Bagozzi (2013), companies that invest a lot in social responsibility can achieve (1) positive impact on customer evaluation of the company; (2) customers feel more connected to the company, and (3) customers feel grateful to the company.

\section{Literature review}

\subsection{Trust: An Important Factor for Success}

Trust is an essential component both in the private and professional markets when building relationships (Paliszkiewicz, 2011). High level of trust can improve democracy, increase economic activity and lead to reduced violence in society (Håkansson, 2015; Paliszkiewicz, 2011). Trust is about an expectation of another person's or a company's actions, that what is being said is right, and the promises are being kept. Therefore, trust is essential to build a long-term relationship with both individuals and companies. Previous research shows that $80 \%$ of customers experience stronger trust in companies that take corporate social responsibility (Gupta and Pirsch, 2006). According to Castaldo and employees (2008) trust is built through proper socially responsible activities which can be a source of success or failure for companies. In other words, trust affects company's profitability.

The trust consumers have for companies can be defined as the expectations they have for the company to take corporate social responsibility, keeping what they promised and be honest, show goodwill and do not show opportunistic behaviour (Tian et al., 2011). A positive experience of community activities can be a crucial factor in succeeding in restoring loyalty after an unfortunate service experience (Choi and La, 2013). Loyalty and trust are closely related to each other; as trust can often be a key factor for a customer to be loyal to a company and its products 
USING OUR COMPETENCE WHEN WE INCORPORATE

Kassaye Deyassa and services. Several investigations have been made on the impact of socially responsible activities on customer's trust in a company. Several researchers have found that corporate social responsibility generally has a positive impact on customers' evaluation of the company, the company's reputation and its activities.

When it comes to trust, it is about the ability to deal with skills, competences and characteristics a company possesses. Ability shows if a company can deliver its products and services as promised to their customers. Trust implies the opposite of opportunistic behaviour. Companies are perceived to show goodwill when customers find that the company genuinely cares about society. Integrity is about the extent to which a person believes that a company behaves in line with its values. Here it is about being consistent in communication and actions if you want to be perceived as a high integrity actor (Mayer et al., 1995).

\subsection{Social Responsibility Connects Customers with Company}

There are several diverse ways a company can demonstrate responsibility for society, for example through sponsorship of a useful purpose, responsibility for the environment or responsibility for company employees, partners and suppliers. Some take social responsibility to strengthen a company's reputation or brand, others do it to make money or because they genuinely care about society. Several hotel chains in Norway work with so-called sustainable social responsibility. They do this by focusing on the environment and asking guests to retain towels if they can be used more than one day. Other companies, such as Huawei, sponsor sports teams like Vålerenga Football. In November 2015, Aftenposten wrote that the OAG would revise how all public companies take social responsibility. The reason for this is critical disclosures in several of the large publicly traded companies. Among other things; it was revealed that Norway's largest bank has been helping customers to operate in tax havens, violating their own corporate social responsibility policies. At this point, Norway's prime minister stated that she was uncertain whether she could trust the bank's management, as the bank did not take corporate responsibility when it came to this event. The example gives a good indication that social responsibility and trust are closely linked to each other.

Park, Lee and Kim (2014) surveyed economic, legal, ethical and philanthropic corporate social responsibility and the impact they have on customers' perception of the company's ability, goodwill and integrity. They found that socially responsible activities generally seem positively affecting the customers' trust in the company, but several types of socially responsible activities affect trust differently. Economic, social responsibility affects only the trust customers have in the company's expertise; philanthropic activities have the greatest impact on customers' perception of company's goodwill, legal and ethical responsibility has the greatest impact on customers' perception of company's integrity (Park et al., 2014). But what happens if the company makes use of its core competence and 
creation of shared value when taking corporate social responsibility? Can any social activity affect all three dimensions of trust: ability, goodwill and integrity? As compliance between social activities and the company has a positive impact on customer evaluation of the company, it is reasonable to believe that the use of the company's core competence can positively impact customers' perception of the company's ability, goodwill and integrity.

\subsection{Creation of Shared Values: A New Form of Corporate Social Responsibility}

Traditionally, socially responsible activities have been implemented independently of what the core competence a company has been. Furthermore, the spotlight has been aimed to increase the profitability of the company. Porter and Kramer (2006) has four reasons why companies incorporate corporate responsibility: moral obligation, sustainability, license to operate and the company's reputation.

\begin{tabular}{ll}
\hline CONCEPT & REASONING \\
\hline Moral Obligation & The company will do what is right. \\
\hline Sustainability & $\begin{array}{l}\text { One should run a company in such a way that those who come } \\
\text { after you get the best possible starting point. }\end{array}$ \\
\hline License to Operate & Company seeks the trust of their stakeholders. \\
\hline Company's Reputation & The company seeks to build the brand or increase share price. \\
\hline
\end{tabular}

The challenge with these four concepts is that companies with this kind of motivation are unable to achieve long-term societal changes or competitive advantages. This weakness led Porter and Kramer (2011) to develop the concept of creating shared values.

Porter and Kramer (2011) argues that companies can achieve long-term societal changes and competitive advantages through the creation of shared values. This can be done by focusing on the mutual interdependence between society and the company. Mutual value creation can be performed by (1) companies and society always acting in a way that benefits both parties, and (2) companies that raise social issues depend on an adaptation between their competence and the social problem. The relationship between a company and its activities can be related to product relevance, similarities in attitudes, geographical similarities, activities and so on. Several studies have been conducted on the correspondence between companies and brand expansion (Aaker and Keller, 1990; Boush and Loken, 1991), company and sponsorship activities (Olson \&Thjømøe, 2011), between country of origin and product / service (Lee et al., 2013) and correspondence between partners in brand alliances (Van der Lanse et al., 2014).
USING OUR COMPETENCE WHEN WE INCORPORATE

Kassaye Deyassa

Table 1.

Why companies incorporate

Corporate Social

Responsibility

Source: Porter and Kramer (2011). 
USING OUR COMPETENCE WHEN WE INCORPORATE

Kassaye Deyassa
As mentioned, several have found that compliance between a company and the choice of activities has positive consequences (Forehand and Grier, 2003; MeyersLevy et al., 1994; Sohn et al., 2012). The better the correspondence between activity and company, the higher the positive impact on customers ' perception of a company's reputation, brand, services and so on. In fact, on the other hand, low levels of compliance could lead to a negative effect on customer's evaluation by the company (Sohn et al., 2012). However, there are no studies that are familiar with who have investigated the effect of trust when there is consistency between the company's competence and socially responsible activity. Companies that use their core competence as a starting point for activities can create higher value for both, the company and society than they do not use core competence (Porter and Kramer, 2006). This is because the company utilises its expertise to create value in society more efficiently. That way, they do not spend unnecessary time and resources to acquire new knowledge. Several companies already utilise their core competencies today to take responsibility for society. For example, Choice Hotels offer free hotel rooms for refugees, and Telenor keeps track of net weight for children and adults to reduce bullying on the internet.

So why should managers and marketers care about creating shared values? As social responsibility is on the agenda, it is useful for managers and marketers to know what activities and criteria are essential for creating value for stakeholders, while creating value for the company. Furthermore, the choice of proper action can give greater confidence to consumers. If the consumer trusts the company, it can help increase sales.

According to Becker-Olsen, Cudmore and Hill (2006), there are three main reasons why compliance between the company and the company's activities is essential. Firstly, when customers experience important levels of compliance, they spend more time thinking about the initiative. Secondly, compliance affects the thoughts the customers make about a company and its activities. If the degree of compliance is low, this can generate negative or less advantageous thoughts as well as help the customer to develop a negative attitude towards the company and activities. Thirdly, compliance has an impact on evaluations soon regarding company, activities and corporate social responsibility. In other words, compliance appears to have a positive effect on and prevent negative evaluation of both; the company and activities. If the company wants to be successful, it is advantageous that the activity and company are consistent.

\subsection{Creation of Shared Values: Economic Benefits, Motivation and Resources}

Creation of shared values is defined as guidelines and operating practices that strengthen the competitiveness of a company while promoting economic and social conditions in society where they operate (Porter and Kramer, 2011). To 
create value for both, the company and customers, the company must exploit its core competence and resources, expertise and insight into its corporate social responsibility. Exploitation of core competencies is perceived as a match between activities and the company. When a company uses its core competencies in socially responsible activities, it can help in increasing customer's confidence in the company (Porter and Kramer, 2011).

There are three reasons why a company should use its core competence when it takes responsibility for the society (Webb, 2014):

1) The company can benefit economically through building knowledge and skills throughout the company, both, in ordinary operations and in socially responsible activities

2) Employees become motivated because the knowledge they have can also help to create value in society.

3) Utilizing core competencies in socially responsible activities is, both, resource-saving and more efficient when the company utilises resources already in possession.

Previously, it was more common to carry out socially responsible activities without considering what resources were used, but more for what purpose should be supported. Recently, more and more people are using their core competence. Whether it is conscious or unconscious, this helps to create shared values. Telenor has a "Use Hue" campaign where they teach children in primary school. Law firms work pro bono, i.e. free, to help those who need legal assistance.
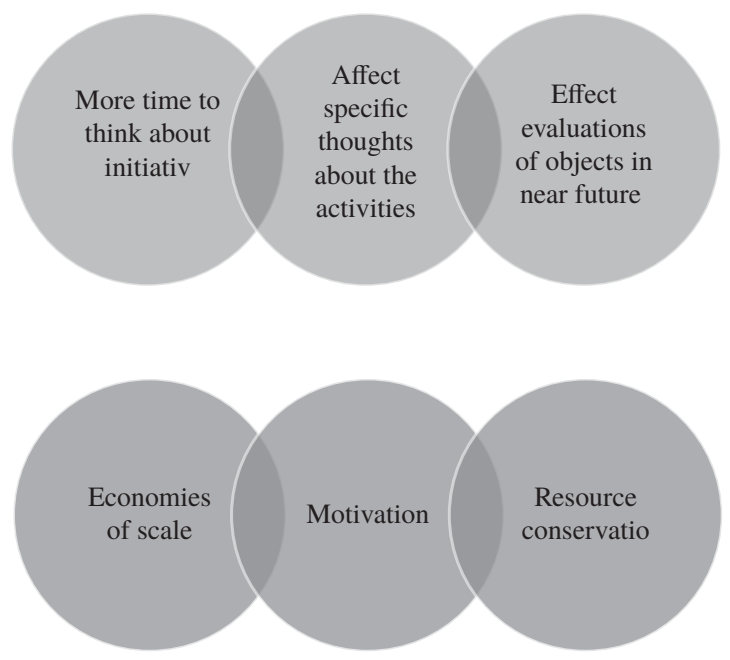

Figure 1.

Why compliance is important?

Source: BeckerOlsen et al. (2006).

Figure 2. Why we use core competencies?

Source: Porter and Kramer (2011) 
USING OUR COMPETENCE WHEN WE INCORPORATE

Kassaye Deyassa

\section{Research method}

\subsection{Research design}

In this survey, the researcher has chosen to focus on the customer domain, in line with the work of Öberseder, Schlegelmilch and Murphy (2013). The customer domain takes customers' perspective and emphasises on customers' expectations of fair treatment, fair prices, and honesty in labelling products, and so on. The researcher personally conducted the study with the help of other three research assistant who played the role of collecting the primary data. The survey involved the use of both primary and secondary data. Published articles, websites and other credible sources were utilized in assessing the findings from the previous researchers. Also, raw data was collected from a selected sample of individuals in both employees', investors' and customers' perspectives. The main aim was to assess how individuals react to companies that uphold activities in corporate social responsibilities. The study involved the general public and not restricted to a particular company. This was meant to ensure adherence to the research objectivity and improve the reliability of the findings. The study was conducted from May to June of the year 2018 the data collected was analyzed in a time frame of one month. Secondary data utilized was restricted to the information published within the past ten years to maintain relevancy. This is because the social needs may vary from time to time depending on the climate conditions. For instance, due to the increased rate of global warming and climate change, CSR activities relating to environmental conservation may be more sensitive in today's organization than they could be in the past (Abeysekera and Fernando, 2018).

\subsection{Target population}

The target population was the public or the members in the society. A sample size of 250 respondents was selected randomly to achieve the objective of the study. Biasness in the sample selection which is one of the major drawbacks of this sampling technique was highly avoided as much as possible. Basic training was provided to the research assistant who was responsible for distributing the questionnaires. The confidentiality of the respondents was also assured to ensure collection of genuine data. Fletcher (2016) connoted that the most of the research participants maybe be unwilling to provide true information or their actual perception due to fear of the consequences that may follow. For example, employees will always avoid revealing the negative activities of their companies whenever this may act as a threat to their job security. This can be avoided by assuring the respondent of his or her anonymity in the study. A balance in the demographic factors was put into consideration throughout the process of collecting data. The information provided was strictly used for the purpose of the study and not in any other mean for personal interest. The researcher took full 
responsibility for the data analysis where a statistical method of linear regression was used in the study. For linear regression, five times as many observations as parameters are required (Janssen et al., 2008). The data collected were analysed with the use of SPSS program which is a common tool for his purpose.

\subsection{Data collection}

Structured questionnaires were used to collect data from the selected sample. Out of the 250 questionnaires issued, 220 were filled successfully and returned on time. The analysis was made based on this number and all the provided percentages are calculated from the total questionnaires returned. Self-administered questions were used. Goddard and Melville (2011) argued that this type of administering questionnaire is more effective since the chances of the researcher influencing the feedback given are also low. However, the researcher was always available both physically and on phone calls to clarify to the participants whenever the need arises. This was to ensure that the respondents have a full understanding of the information required and hence, the findings would not be compromised by the misunderstanding. The questions were designed to address the key variables in the study which include the ability, goodwill and the integrity in developing trust with organizations. The questionnaire included three major sections which intended to capture the respondents' opinion from all the perspectives ranging from employees, customers and investors/shareholders. The questions allowed the participant to give their brief comparison on how the perceive organizations that are sensitive to giving back to the society in which they are operating in. Demographic features of the respondent were also captured in the questionnaire as well as their occupation. The sample distribution was evenly modified to ensure inclusion of all individuals and improve the practicability of inferences made. Individuals' perception of corporate social responsibility may vary with age, gender, and even social class of the respondent.

The researcher minimized the sampling error through a selection of a true replica of the target population. It is difficult to obtain $100 \%$ characteristics of the target population with the use of samples (Lawrie, 1978). This challenge was addressed through the adoption of random sampling and upholding objectivity in throughout the study. Sampling error can also be minimized by increasing the sample size. However, time and financial resources were major constraints in this researched which dictated a narrower sample size to be used. The questions asked were directly or indirectly answering the objectives of the survey. Both open and closed-ended questions were used. For example, the respondents were asked closed-ended questions such as; "do you believe that organizations should invest in activities that are benefiting the society?" Also, the shareholders' section included the question of assessing their trust in corporate social responsibility activity. The questionnaire also included other open-ended questions such as "How do
USING OUR COMPETENCE WHEN WE INCORPORATE

Kassaye Deyassa 
USING OUR COMPETENCE WHEN WE INCORPORATE

Kassaye Deyassa you think that firms investing in CSR are better than those that do not?" The overall questions were intended to investigate the level of trust of the respondents towards the organizations that adhere to corporate social responsibility activities. The findings were generalized and appropriate analysis tools applied to arrive at a conclusion.

\section{Ability: To Deliver Quality Service and to Take Care of the Society}

Ability is about the skills, competencies and characteristics a company have (Mayer et al., 1995). Whether a company can deliver quality products and services is an example of how the customer assesses a company's ability. Both, corporate social responsibility and the company's ability, have a direct positive effect on customers' confidence in a company. Taking responsibility for society shows that the company can do more than just thinking about daily operations and activities directly related to buying and selling. Nevertheless, it is important that the customer does not feel that corporate social responsibility is at the expense of company deliveries, as this will impair customer's perception of a company's ability. If you take this into account when a company takes social responsibility, there is much to suggest that compliance will have a positive impact on customer confidence in the company's ability. Companies that communicate economic stability and security are helping in building the trust customers have in their ability to deliver. When there is a correspondence between the company's social activity and its core competence, the company shows that it can effectively allocate appropriate resources to contribute to society (Porter and Kramer, 2011). Several studies show that compliance has a positive effect on customers' evaluation of the company, and social responsibility has, generally, a positive effect on the perception of a company's ability. Therefore, the researcher can ask the following question: To what extent is the customer's experience affected by company's ability when there is high versus a low degree of compliance between core competence and social activity?

\section{Goodwill: Does the Consumer Trust that Companies Wish Others Good?}

Goodwill is about whether a consumer trusts that a company wishes to help others and do well for them and does not work solely for personal gain. Social activities based on honesty and openness show that the company sincerely acts from a customer's interest, and not only for the company's benefit (Mayer et al., 1995). Goodwill is a factor that must be true for customers to get a good sense of activities a company performs. Although there is little research on the direct impact of community activities on customer's perception about company's goodwill, there is a reason to believe that the relationship is significant when the goal is to build trust in customers. However, studies show that if there is a low degree of coherence between the activity and company's competence, it may 
have a negative effect on customer's evaluation of company; irrespective of its motivation. Furthermore, the perception of the motivation behind social activity has an impact on whether the company is perceived to have goodwill or not. When a company uses its core competency instead of going beyond its own business to impress customers, this can show that they genuinely care about their customers. Therefore, the conformity of compliance contributes to increasing value for both customers and the company. This leads to the question: To what extent customer's perception of the company's goodwill is influenced when there is high versus low degree of compliance between core competence and social activity?

\section{Integrity: How Important is Fairness and Sincerity for the Customer?}

Integrity is about a company being consistent in its actions and acting fairly towards its employees, customers and suppliers. A company can show integrity by taking corporate social responsibility (Maak, 2008). For it to work, it is essential that the company shows it is not only for its gain but also to create value for its customers, which can be related to the experience of fairness. A crucial factor in business is that executives who are perceived to have a high degree of integrity often tend to take responsibility for society (Brown, 2005). Therefore, having such leaders in the company can lead the company to take responsibility for society and, thus, is perceived to act with a high degree of integrity. When we agree with the assessment of a relationship between social responsibility and impact on integrity, we agree to display consistency in a company's actions, and consistency in actions is part of the integrity. Furthermore, a company can be perceived as fair in its actions when it uses excess resources to create value for the customer, and not for its gain. This leads us to the question: To what extent the customer's perception of the company's integrity is influenced when there is a high versus low degree of compliance between core competence and social activity?

\section{Experiment: How to Investigate Sustainable Trust?}

To clarify the above question, the researcher compared the impact of social responsibility (low degree of consistency between activity and competence) and creation of shared values (high level of consistency between activity and competence) on different dimensions of trust. This was tested in three groups: a group of social responsibility, one for the creation of shared values and a control group. The control group was only exposed to a description (a scenario) of the company and not an activity (see Appendix 1). Respondents were randomly assigned among three groups. This means that one group was exposed to the control scenario, one to the low level of compliance between activity and competence, and one to the scenario with a high degree of compliance between activity and competence. Then each respondent filled out a questionnaire consisting of the same questions. The only things that distinguished the descriptions of companies 
USING OUR COMPETENCE WHEN WE INCORPORATE

Kassaye Deyassa were the name and core competence. Fictitious companies were used to prevent existing associations that may affect performance (Klein and Dawar, 2004).

The population the researcher wanted to investigate was the Norwegian population over 18 years. In order to get sufficient assortment for the results to be generalised, convenience principles were used (Malhotra, 2010). In practice, this meant that recruitment was done via Facebook networking. This means there is a risk of getting a skewed selection, so you cannot say that the choice is representative of the population.

In the scenarios, the telecommunications and aquaculture industries were used as a context. These industries were utilised since they are essential to the national economy through the employment of thousands of people. Besides, the telecommunications industry manages vital infrastructure in the country. The aquaculture industry is a supplier of a substantial portion of food in Norway. In both sectors, trust is important for community engagements.

Ability, goodwill and integrity were measured through questions used in the works of Mayer and Davis (1999) and Schlosser, White and Lloyd (2006). The researcher used six questions for ability, five for goodwill and four for integrity. The questions were measured on a five-point Likert scale (Mayer and Davis, 1999; Schlosser et al., 2006).

The criteria for creation of shared values (high level of compliance) was achieved when the fictitious farming company, farming AS used its core competence in processing fish in the performance of social activity seafood courses. This creates value for society by making people better able to eat fish, which is recommended by the health authorities (Helsenorge, 2016). It creates value for Farming AS by stimulating higher demand for their product. This combination creates shared values. In the social responsibility scenario, the criteria for creating shared values are not achieved when the fictional telecommunications company Telecom AS performs the social activity seafood courses (low level of compliance). There is still a social responsibility, but it does not ensure efficient resource utilisation or added value for Telecom AS. A pre-test was conducted to ensure high corporate and social responsibility in creating the shared value scenario and correspondingly low compliance with the CSR scenario. The relationship between three companies and three activities were controlled among 40 respondents. To test the match, the three compliance questions from Speed and Thompson (2000) were adapted and measured on a seven-point Likert scale. The result of the pre-test showed there was a high level of consistency between farming PLC and seafood courses (average $=5.34, t=27.510, p=0.000$ ) and low compliance between Telecom PLC and seafood courses (average $=1.70, \mathrm{t}=$ $15.785, \mathrm{p}=0000$ ). There were also significant differences between the companies on other social activities, but for the seafood courses, the biggest differences were present. 


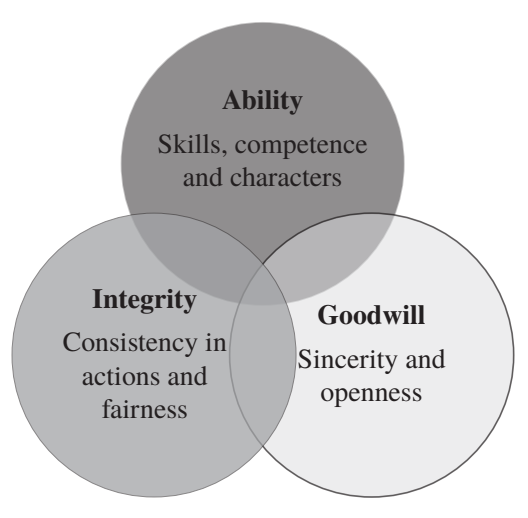

USING OUR

COMPETENCE WHEN

WE INCORPORATE

Kassaye Deyassa

Figure 3.

Three dimensions

of trust

Source: Porter and

Kramer (2011).

\section{Analysis}

With five parameters (ability, goodwill, integrity, corporate social responsibility and the creation of shared values), a minimum of 25 unique respondents was used. Therefore, 220 respondents exceeded the requirements for the size of the sample with a good margin. The selection shows a certain spread. Of the respondents, $53.2 \%$ were men, and $46.8 \%$ were women with an average age of 36.4 years. 16 of Norway's 19 counties were represented in the committee. $38 \%$ of respondents were from Western Norway (Rogaland, Hordaland, Sogn and Fjordane) while 47\% were from central Eastern Norway (Oslo and Akershus).

Regression analysis was carried out with SPSS program to find the correlation coefficients of the research variables. The results were represented in a table form which shows the Pearson correlation coefficient ( $r$ ), the coefficient of determination $(\mathrm{r} 2)$, the $\mathrm{P}$-value $(\mathrm{p})$. The results reveal that there is a positive correlation between all the independent variables and the corporate social responsibility. This indicated that the corporate social responsibility is a vital competitive tool to the firms which utilize it. Higher correlation coefficients are associated with the significant impact of the CSR strategies to the overall organizational performance. The P-value has also indicated that correlation is significant in the study. The analysis was done at a 95\% confidence level. The explanatory of the deliverables was based on the occupation of the respondents which was divided into three perspectives; that is, the employees, customers and the shareholders.

To determine what effect, if any in general, social responsibility and the creation of shared values have on trust, linear regression analyses were performed in the SPSS statistical program. The values in regression showed that $5.4 \%$ of the variation in ability leads to trust that could be explained by social responsibility and the creation of shared values, $4.9 \%$ for goodwill and $4 \%$ for integrity. This indicated that corporate social responsibility and the creation of shared values explain a small part of the trust a company receives. Therefore, it is likely that 
USING OUR COMPETENCE WHEN WE INCORPORATE

Kassaye Deyassa

Table 2. The results of the linear regression analysis

Source: own research. other factors that are not highlighted in this study have a more significant effect on trust. But we know that a low-explained variance is common when examining human behaviour (Minitab, 2013). Therefore, the researcher believe that he can still make meaningful conclusions from these results.

\begin{tabular}{lccccccccc}
\hline & \multicolumn{1}{c}{ Linear Regressions } \\
& \multicolumn{1}{c}{ Ability } & \multicolumn{1}{c}{ Goodwill } & \multicolumn{3}{c}{ Integrity } \\
\cline { 2 - 11 } & B & t & To. & B & t & To. & B & t & To. \\
\hline Constant & 2,768 & 36,513 & $\mathbf{0 , 0 0 0}$ & 3,163 & 29,735 & $\mathbf{0 , 0 0 0}$ & 3,361 & 33,156 & $\mathbf{0 , 0 0 0}$ \\
\hline CSR & $-0,273$ & $-2,481$ & $\mathbf{0 , 0 1 4}$ & $-0,091$ & $-0,586$ & 0,559 & $-0,129$ & $-0,879$ & 0,381 \\
\hline CSV & 0,123 & 0,896 & 0,371 & 0,376 & 2,551 & $\mathbf{0 , 0 1 1}$ & 0,281 & 2,024 & $\mathbf{0 , 0 4 4}$ \\
\hline $\mathbf{R}^{\mathbf{2}}$ & 0,054 & & & 0,049 & & & 0,040 & & \\
\hline
\end{tabular}

\section{Ability-Trust: Negative Impact of CSR}

When the researcher compared corporate social responsibility and the creation of shared values, he found that social responsibility has a significant $(\mathrm{p}=0.014)$ negative $(\mathrm{B}=-0.273)$ effect on ability. The researcher also found that creation of shared values has a positive $(B=0.123)$, but not statistically significant ( $p$ $=0.371$ ), impact on ability-based trust when compared to corporate social responsibility. These results show that respondents' trust in the company's ability is not significantly affected by the creation of shared values, that is, a high level of compliance between the company and social activity. They also indicate that corporate social responsibility with low compliance between the company and social activity has a negative effect on a company's ability to trust. The correlation coefficients we as follows; ability 0.2323 , goodwill 0.22 and the integrity had a correlation of 0.200 . This implies that there is a positive correlation with all the independent variables and the corporate social responsibility.

\section{Goodwill-Trust: Positive Effect of Creation of Shared Value}

Corporate social responsibility has a negative $(B=-0,091)$, but non-significant $(\mathrm{p}=0.559)$, effect on goodwill trust. Creation of shared values has a significant $(\mathrm{p}=0.011)$ and positive $(\mathrm{B}=0.376)$ effect on goodwill trust. Thus, respondents' perception of the company's goodwill is not significantly affected by a company performing a social activity with low compliance with its core competence. However, if there is a high level of compliance between the social activity and the company through the creation of shared values, the company has a positive effect on how respondents perceive their goodwill.

\section{Integrity-Trust: Positive Effect of Creation of Shared Values}


$(p=0.381)$, impact on integrity trust. Creation of shared values has a significant $(p=0.044)$ and positive $(B=0.281)$ effect on integrity trust. Thus, respondents' perception of the company's integrity is not significantly affected by a company performing a social activity with low compliance with its core competence. However, if there is a high level of compliance between social activity and the company through the creation of shared values, the company has a positive effect on how respondents perceive its integrity. When the researcher compared B-values to goodwill $(\mathrm{B}=0.376)$ and integrity $(\mathrm{B}=0.281)$, The researcher observed that creation of shared values has the greatest effect on goodwill, but effects are positive and significant on both.

\section{Discussion}

\subsection{Summary of the results}

The researcher does not find support for the creation of shared values to have a greater positive effect on ability-based trust than traditional corporate social responsibility, which does not emphasise the correspondence between activity and company's competence. This indicates management in companies that do not take corporate responsibility should also not use the creation of shared values to increase trust in the company's ability. But that does not mean the creation of shared values has nothing to say about developing sustainable trust ties with customers. The researcher found a negative impact of corporate social responsibility on ability-based trust. This means that management in companies that take corporate social responsibility should benefit from the principles of creating shared values to avoid a negative impact on a company's ability to trust. By creating shared values, companies, who take corporate social responsibility, ensure sustainable management of their ability to trust by avoiding negative effects.

The researcher found that creating shared values has a positive effect on goodwill and integrity-trust. Creating shared values also has a positive impact on goodwill and integrity-trust than traditional corporate social responsibility. The researcher found no significant impact of corporate social responsibility with low compliance between company and activity on goodwill and integrity-trust. Social responsibility that does not give anything back to the companies can hardly be called sustainable. Companies that follow the principles of creating shared values when taking corporate social responsibility will get back regarding increased willingness and integrity trust. A social responsibility that creates values for both society and the company taking responsibility can be called sustainable. This shows that management in companies wishing to increase trust in their goodwill and integrity should implement community activities with high compliance with the company according to the principles of creation of shared values. 
USING OUR COMPETENCE WHEN WE INCORPORATE

Kassaye Deyassa
A weakness of the study is the low explained variance (R2). This suggests that there are other factors which have a greater impact on trust than social responsibility and the creation of shared values. It may be interesting for further research to look at what factors might be. A potential source error in the study is the use of scenarios. Scenarios are fictitious situations, so they may have influenced the results in a different direction from what would have been the case in actual situations. Another error source that may have a similar effect is the use of fictitious company names. This was used to prevent respondents' attitudes towards existing companies from affecting the answers, but this might be an incorrect source. Nevertheless, the results show a clear direction. Further, research can focus on testing if one achieves related results for the impact of social responsibility and the creation of shared values in a realistic situation.

This article supports the argument of Porter and Kramer $(2006 ; 2011)$ that companies which exercise social responsibility most efficiently will get back to this. The article also supports the findings of Becker-Olsen, Cudmore and Hill (2006) and Forehand and Grier (2003) that greater compliance in a context reduces negative thoughts and attitudes of the public towards a company.

This study supports two recommendations for companies. When the goal is to build trust among customers: 1) Corporate social responsibility with a low degree of consistency between activity and company is ineffective and in part negative; 2) However, corporate social responsibility with a high degree of compliance (creation of shared values) can be the key to success.

\subsection{Comparison of the research findings with the other studies}

The research conducted by Becker-Olsen, Cudmore and Hill (2006) showed that there is a strong relationship between the corporate social responsibility and the profitability of the firm. The study was conducted on various private companies and their investment in social activities compared to the firm's profit margin. My research has shown that customers tend to develop more trust in companies that are sensitive to corporate social responsibility activities. This creates a competitive advantage for that firm and hence, the ability to acquire a larger market share compared to their rivals. Another research conducted by Choi and La (2013) supported the argument that the public tends to develop a positive attitude towards companies that add value to the society. The results of the Becker-Olsen, Cudmore and Hill (2006) showed a strong correlation between the financial performance of the firm and the corporate social responsibility efforts.

Even though the article by Klein and Dawar (2004) categorizes corporate social responsibility as an avoidable expense, other scholars have classified it as an expense which can be capitalized. Research has shown that the rate of return with 
the CSR investment is always high ranging from the employees' perspectives to the customer's perspective. The study showed that the workers are highly motivated when working in an organization that values the society that surrounds them. CSR may involve broad activities including creating employment opportunities in the

USING OUR COMPETENCE WHEN WE INCORPORATE

Kassaye Deyassa nation. Individuals have a definite sense of belonging when they are working for an organization that is recognized for improving the well-being of the community. This increases their productivity and creates a competitive advantage. My study indicated that most of the shareholders do not support the idea of corporate social responsibility as they do not perceive its importance. The strategy may raise some accountability issues since it is not always easy to assess the monetary value of the investment made on the social activities. The cost incurred on such activities is recovered from the increased volume sales. Therefore, much of the research conducted shows that CSR is highly recommended to the firms that need to achieve their intended goals and objectives. Further research is recommended on the influence of the legal framework on the implementation of corporate social responsibility.

\section{Conclusion}

In this survey, the researcher looks at the concept creation of shared values, and the impact this can have on the trust consumers have in companies. Trust consists of three dimensions: ability, kindness and integrity whereas others have researched the impact of corporate social responsibility on trust and investigated the effect of creating shared values on the perception of different sides of trust, that is, ability, benevolence and integrity.

In this study, the researcher looked also at the CSV concept and what effects it has on customer's trust in companies, how customers experience a company's ability, goodwill and integrity. The researcher compared the impact of corporate social responsibility on customer's trust in the company with respect to low and high levels of compliance between community activity and the company's core competence.

The results show that high levels of compliance between social activity and competence have a positive impact on customers' perception of the company's goodwill and integrity but have no effect on how customers assess company's core competence. When the compliance between activity and core competence is lower, an effect on customer assessment of a company's competence is negative. The findings have implications for leaders regarding the priorities that should be made to build trust by taking corporate social responsibility into consideration. Proper activities are important to increase a customer's trust in the company. Increased trust among customers paves the way to increased loyalty and positive review of the company; which ultimately affect a company's profitability. 
USING OUR COMPETENCE WHEN WE INCORPORATE

Kassaye Deyassa

\section{References}

Aaker, A., Keller, K. (1990), “Consumer Evaluations of Brand Extensions”, Journal of Marketing, Vol. 54 No. 1, pp. 26-40.

Abeysekera, A., Fernando, C. (2018), "Business Social Obligation vs. Corporate Social Obligation: A Household Perspective", SSRN Electronic Journal, pp. 44-64.

Becker-Olsen, L., Cudmore, B., Mountain, P. (2006), “The impact of the company's social duty on customer actions", Journal of Company Study, Vol. 59 No. 1, pp. 45-52.

Becker-Olsen, K., Simmons, C.J. (2002) ,"When Do Social Sponsorships Enhance Or Dilute Equity? Fit, Message Source, and the Persistence of Effects", in: Broniarczyk, S.M., Nakamoto, K. (Eds.), Advances in Consumer Research, Association for Consumer Research, Valdosta, pp. 287-289.

Boush, D., Loken, B. (1991), "A treatment for tracking the brand name expansion", Journal of Marketing Study, Vol. 28 No. 1, pp. 15-27.

Brown, T. (2005), Company Stability, Confirmation of Company Values and also Control, Cambridge University Press, New York.

Carroll, B. (1991), "The Pyramid for Social Duty: For a Lesson Monitoring of Company Rate of In-terests", Corporate Horizons, Vol. 35 No. 4, pp. 37-48.

Castaldo, S., Perrini, F., Misani, N., Antonio, T. (2008), "The absence of a web link in between the social dedication of firms as well as adding the suffering of customers: the problem of affordable trade products", Journal of Company Integrities, Vol. 84 No. 1, pp. 1-16.

Choi, B. (2013), "The impact of CSR (CSR) and also customer confidence assistances rejuvenate and likewise heal engagement after a failing", Journal of Provider Marketing, Vol. 27 No. 3, pp. 222-232.

Fletcher, A. (2016), "Use of Important Practical Look in Qualitative Research Study Research Study: Procedure Approaches Method", International Journal of Social Research Technique, Vol. 20 No. 2, pp. 180-193.

Forehand, R., Grier, S. (2003), "When is frankly one of the loveliest methods?'The result of a noticeable commitment to buyer anxiety", Journal of Individual Psychology, Vol. 13 No. 3, pp. 349-356.

Goddard, W., Melville, S. (2011), Research Technique, Juta \& Co., Kenwyn, South Africa.

Gupta, S., Pirsch, J. (2006), "The choice of the provider to confirm marketing and advertising", Journal of Buyer Marketing, Vol. 23 No. 6, pp. 313-325.

Helsenorge (2016), Nutritional Relevant information: Normally eat fish, available at: https://helsenorge.no/kost-og-ernaring/kostrad/eat-fish-typical (accessed 25 April 2018).

Herzberg, F., Mausner, B., Synderman, B. (1959), The Motivation to Work, John Wiley $\&$ Sons, New York.

Janssens, W., Wijnen, K., Pelsmacker, P.D., Kenhove, P.V. (2008), “A social network in addition to checking - an arranged recommendation", Journal of Company and Economics, Vol. 6 No. 3, pp. 516-523.

Klein, J., Dawar, N. (2004), "Business devotion in addition to additionally client qualities and also brand name examinations in a short article circumstance", International Journal of Research in Ad-vertising, Vol. 21 No. 3, pp. 202-216. 
Koo, T. (2016), "Business social task and also firm productivity”, SSRN Electronic Journal.

Lawrie, N. (1978), "Sampling”, International Journal of Operational Research, Vol. 2 No. 2.

Lee, K., Lee, K., Lee, N. (2011), "Property of Roots Fit Result in Analysing Customer Products in Cross-Border Essential Label Alliance", Journal of Business Research, Vol. 66 No. 3, pp. 354-363.

Make, T. (2008), "Excluded Company Task: Toward a Concept of Entrepreneurial Stability", Journal of Service Integrities, Vol. 82 No. 2, pp. 352-367.

Malhotra, N. (2010), Market assessment: job alignment, Pearson Education and Learning, New Jersey.

Mayer, C., Davis, H. (1999), "The result of the efficiency assessment unit on the dependence on the administration: a region practice", Journal of Applied Psychological Science, Vol. 84 No. 1, pp. 122-135.

Mayer, C., Davis, H., Schoorman, D. (1995), “An incorporated model of organisational trust fund", Institute of Administration Assessment, Vol. 20 No. 3, pp. 708-733.

Meyers, J., Louie, T., Curren, T. (1994), "Just how carries out Market branding affect brand-name registration?", Journal of Applied Psychological Science, Vol. 79 No. 1, pp. 45-52.

Minitab, H. (2013), "Regression assessment: Exactly how do I analyze squares and also look at the match?", available at: http://blog.minitab.com/blog/adventures-in-statistics/ regression analysis-how-do-i-artist-squared-andessess-the-goodness-of-fit (accessed 2 March 2018).

Öberseder, M., Schlegelmilch, B., Murphy, E. (2013), “CSR technique in addition to customer expectations", Journal of Company Study, Vol. 66 No. 10, pp. 1838-1850.

Olson, B., Thjømøe, M. (2011), "Discuss and verbalise the in-form style in sponsorship", Journal of Marketing, Vol. 40 No. 1, pp. 56-71.

Paliszkiewicz, O. (2011), "Leave Administration: Literature", Monitoring, Vol. 6 No. 4, pp. 314-330.

Park, J., Lee, H., Kim, C. (2014), "Business Social Accountability, Consumer Confidence, and additionally Provider Image: South Korean Customers' Viewpoint”, Journal of Service Study, Vol. 67 No. 3, pp. 294-301.

Porter, M., Kramer, R. (2006), "Strategy and society: The link between corporate social responsibility and competitive advantage", Harvard Business Review, Vol. 84 No. 12.

Porter, M., Kramer, M. (2011), "Creating shared value”, Harvard Business Review, Vol. 89 No. $1 / 2$, pp. 62-77. 